\title{
KAJIAN LITERATUR: DAMPAK COVID-19 TERHADAP PENDIDIKAN JASMANI
}

\section{LITERATURE REVIEW: THE IMPACT OF COVID-19 ON PHYSICAL EDUCATION}

\author{
Muhammad Syofian ${ }^{1 *}$, Novri Gazali² \\ 1,2Pendidikan Jasmani Kesehatan dan Rekreasi, Universitas Islam Riau, Pekanbaru, Indonesia \\ *Corresponding Author: Muhammad Syofian, muhammadsyofian@student.uir.ac.id
}

Received: 2021-02-24; Revised: 2021-05-04; Accepted: 2021-05-27

\begin{abstract}
Abstrak
Covid-19 mengharuskan kita melakukan pembatasan skala besar dan melakukan aktivitas dari rumah saja guna memutus penyebaran Covi-19. Aktivitas yang terdampak dari adanya Covid-19 adalah sektor pendidikan mengalami pergeseran pelaksaan yang dilakukan pembelajaran berdasarkan elearning dari rumah saja. Tujuan penelitian untuk mengetahui dampak Covid-19 terhadap pendidikan jasmani. Hal ini sangat dibutuhkan untuk mengetahui implementasi dan dampak pembelajaran pendidikan jasmani di masa pandemic covid-19 saat ini, dengan harapan dapat memberikan informasi Metode yang digunakan studi literatur atau tinjauan pustaka. Studi literatur adalah desain penelitian yang digunakan dalam mengumpulkan sumber data yang berkaitan dengan suatu topik. Pengumpulan data untuk studi literatur dilakukan dengan alat pencarian database yang sebagai tahapan pencarian sumber literatur. Pengumpulan data menggunakan metode preferred Reporting Items for Sistematic Reviews AND Meta Analysis (PRISMA). Hasil screening yang sesuai dan yang dibutuhkan terdapat 8 artikel Jurnal Nasional dan 7 artikel Jurnal Internasional. Berdasarkan artikel yang ditemukan dan dianalisis terdapat dampak postif serta negative yang ditimbulkan oleh virus covid-19 terhadap pembelajaran penjas diulas berdasarkan kajian literatur hasil penelitian terdahulu.
\end{abstract}

Kata Kunci: Dampak, covid-19, pendidikan jasmani

\begin{abstract}
Covid-19 requires that we carry out large-scale restrictions and carry out activities from home only to stop the spread of Covi-19. Activities affected by the existence of Covid-19 are the education sector experiencing a shift in the implementation of learning based on e-learning from home only. The research objective was to determine the impact of Covid-19 on physical education. This is very much needed to determine the implementation and impact of physical education learning in the current Covid-19 pandemic, with the hope of providing information on the methods used in literature studies or literature reviews. Literature study is a research design used in collecting data sources related to a topic. Data collection for literature studies was carried out using a database search tool as a stage of searching for literature sources. Data collection uses the preferred Reporting Items for Systematic Reviews AND Meta Analysis (PRISMA) method. The screening results that are appropriate and needed are 8 National Journal articles and 7 International Journal articles. Based on the articles that were found and analyzed, there were positive and negative impacts caused by the Covid-19 virus on Physical Education learning, which were reviewed based on a literature review of previous research results.
\end{abstract}

Keywords: Impact, covid-19, physical education.

How to Cite: Syofian, M., \& Gazali, N. (2021). Kajian Literatur: Dampak Covid-19 Terhadap Pendidikan Jasmani. Journal of Sport Education (JOPE), 3 (2), 93-102. doi: http://dx.doi.org/10.31258/jope.3.2.93-102

Journal of Sport Education (JOPE) is an open access article under the CC-BY-SA 4.0 


\section{PENDAHULUAN}

Pada akhir tahun 2019 tepatnya pada tanggal 31 Desember 2019, WHO yang merupakan Organisasi Kesehatan Dunia mengumumkan tentang munculnya sebuah kasus pneumonia etiologi terdeteksi di kota Wuhan, Cina (Lee, 2020) dan cepat menyebar ke seluruh Cina (Guan et al., 2020). Organisasi Kesehatan Dunia mengatakan bahwa coronavirus baru yang sejauh ini telah menyebar dari Cina ke 26 negara di seluruh dunia tampaknya tidak seperti virus mematikan lainnya termasuk SARS dan MERS (Mahase, 2020).

Sampai saat ini, banyak pasien yang terinfeksi SARS-CoV-2 memiliki gejala demam, sakit pada tenggorokan, dan juga batuk ringan. Banyak kasus telah ditangani dengan cepat. Beberapa kasus berkembang menjadi sebuah komplikasi yang sangat fatal yang menyebabkan gagalnya organ, syok septik, edema paru, pneumonia, dan Gangguan Pernafasan Akut (ARDS) (Sohrabi et al., 2020). Perlu diketahui terdapat tujuh jenis virus corona yang dapat menginfeksi manusia yaitu: 229E, NL63, OC43, MKU1, MERS-CoV, SARSCoV (Kurniawan, 2020).

Pandemi (COVID-19) mengacaukan sistem kesehatan, mematikan ekonomi, dan banyak sektor lainnya terutama pendidikan (Rundle et al., 2020). Guru harus mengikuti setiap kebijakan pemerintah serta mencari cara agar pembelajaran dapat terlaksana meski belajar di rumah. Meski model pembelajaran belajar dirubah tetapi sebenarnya relatif sama tujuannya dan yang membedakan adalah sarana dan prasarana pendukung yang digunakan karena konsep pembelajaran menggunakan metode e-learning (Kurniasih, 2020).

Sama seperti negara yang terdampak lainnya, Indonesia mulai dari aspek ekonomi, kesehatan dan tidak terkecuali pendidikan mendapatkan dampaknya. Untuk memutus rantai penularan covid-19 Pemerintah Indonesia memutuskan untuk pembelajaran tatap muka ditiadakan mulai dari jenjang pendidikan SD sampai perguruan tinggi (Kurniawan, 2020).

Sistem pembelajaran melalui e-learning berdampak juga pada pembelajaran penjas baik itu yang positif maupun yang negatif. Covid-19 telah membuat semua pendidikan dilakuan secara Work From Home (Purwanto, 2020). Sejalan dengan penjelasan tersebut, Herlina dan Suherman (2020) mengungkapkan jika pembelajaran penjas saat Covid-19 dilakukan melalui media seperti Zoom dan Google Meet serta komunikasi lainnya mengalami kesulitan dalam penyampainya. Hudah et al., (2020) mengungkapkan jika pembelajaran yang dilakukan berbasis teknologi ini cukup menyulitkan bagi guru yang sudah memasuki usia 40 tahun sehingga pembelajaran ataupun materi yang diberikan tidak maksimal. Guru dengan batas usia tersebut memberikan pembelajaran melalui Whatsapp. Berdampak dari adanya pandemi Covid-19 mengharuskan pembelajaran penjas dilaksanakan melalui daring. Lebih lanjut dijelaskan bahwa pembelajaran penjas melalui daring berdampak pada tidak efektifnya pembelajaran yang berlangsung (Sulaksono \& Wibowo, 2021).

Berdasarkan permasalahan yang ada mengenai dampak Covid-19 pada pembelajaran penjas yang dilakukan secara e-learning. Penelitian bertujuan untuk melakukan review mengenai bagaimana dampak Covid-19 terhdap pembelajaran penjas yang dilakukan melalui e-learning. Penelitian ini dirasa sangat penting dilakukan guna mengetahui bagaimana pembelajaran penjas yang berlangsung selama Covid-19. Hasil peneltian diharpkan mampu memberikan gambaran serta informasi mengenai pembelajaran penjas serta diharpkan mampu menjadikan rujukan untuk memberikan informasi penggunaan media yang sesuai dalam penyampaian pembelajaran penjas saat Covid-19.

\section{METODE}

\section{Jenis Penelitian}

Metode yang digunakan studi literatur atau tinjauan pustaka. Studi literatur adalah desain penelitian yang digunakan dalam mengumpulkan sumber data yang berkaitan dengan suatu topik. Studi literatur bertujuan mendeskripsikan konten pokok berdasarkan informasi 
yang didapat (Herliandry et al., 2020).

Mengumpulkan Artikel

Pengumpulan data untuk studi literatur dilakukan dengan alat pencarian database yang sebagai tahapan pencarian sumber literatur. Pengumpulan data ini menggunakan metode Preferred Reporting Items for Systematic Reviews and Meta Analysis (PRISMA). Penelitian dilaksanakan dengan menganalisis jurnal dan kemudian membuat ringkasan yang berkaitan dengan pertanyaan dan tujuan dari penelitian. Prosedur pencarian jurnal untuk menjadi sebuah bahan dalam penelitian ini yaitu memiliki kriteria yang sesuai dengan prosedur PICOT. Pertanyaan yang digunakan untuk melakukan review pada jurnal telah disesuaikan dengan metode PICOT, setiap pertanyaan terdapat $\mathrm{P}=$ problem $/$ population.

Penelitian ini menggunakan pembelajaran sebagai problem. I/E= implementasi/intervensi/exposure, peneliti meneliti hal apa yang terjadi pada pembelajaran pendidikan jasmani dalam masa pandemi Covid-19. $\mathrm{C}=$ control/intervensi pembanding, peneliti tidak menggunakan intervensi perbandingan ataupun control dalam penelitian. $\mathrm{T}=$ time/waktu, peneliti melakukan penelitian review jurnal dalam masa pandemi Covid-19 untuk mengetahui seperti apa kegiatan pembelajaran pada masa pandemi Covid-19.

\section{a. Metode Pengumpulan}

Strategi yang dilakukan dalam pencarian literatur didapatkan melalui database penyedia jurnal nasional dan internasional. Database penyedia jurnal yang bersifat nasional dan internasional dapat diakses melalui beberapa website.

\section{b. Akses Penulisan}

Akses yang dipakai untuk pencarian artikel yang direview menggunakan database pencarian dari google scholar, eric, dan juga scopus yang kemudian menggunakan search term Dampak covid-19 terhadap pendidikan jasmani.

\section{c. Rentang Waktu Artikel}

Rentang waktu artikel pada tahun 2020 dikarenakan pembelajran E-learning terdampak Covid-19. Penelitian ini menggunakan kriteria inklusi 15 daftar pustaka. Tahapan mengidentifikasi artikel terlebih dahulu dengan temuan sebanyak 192 artikel di Google Scholar, 335 artikel pada Eric dan juga 44 temuan artikel di Scopus. Selanjutnya artikel tersebut di screening menjadi 30 artikel nasional dan 20 artikel internasional. Hasil screening yang sesuai dan yang dibutuhkan terdapat 8 artikel Jurnal Nasional dan 7 artikel Jurnal Internasional. Untuk mempermudah dari Metode dapat dilihat pada gambar 1.

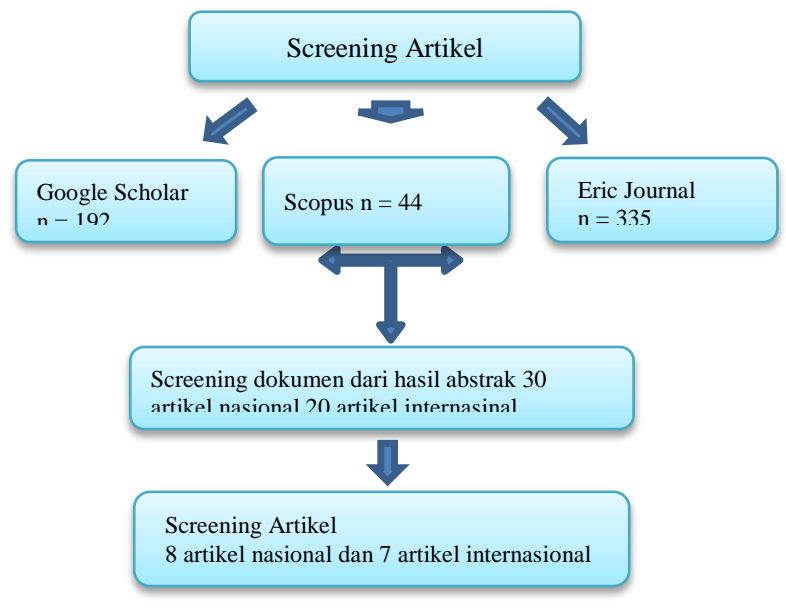

\section{HASIL}

Gambar 1. Gambar Bagan Screening Artikel

Hasil penelitian yang akan disajikan terbagi menjadi dua table yang akan menemampatkan mengenai jurnal yang dilakukan kajian literatur. Table 1 akan menampilkan 
hasil penelitian meliputi, Tahun Terbit Artikel, Nama Jurnal, Jenis Terbitan. Setelahnya tabel 2 akan menampilkan mengenai hasil analisis kajian literatur meliputi Nama Penulis, Desain Penelitian dan hasil Penelitian. Untuk mempermudah melihat hasil penelitian akan disajikan pada tabel 1.

Tabel 1. Publikasi Jurnal Terindeks

\begin{tabular}{|c|c|c|c|}
\hline Tahun & Nama Jurnal & Jumlah Artikel & Jenis Terbitan \\
\hline 2020 & SoCarXvi & 1 & $\mathrm{Q} 2$ \\
\hline 2020 & $\begin{array}{l}\text { Obesity (Silver } \\
\text { Spring) }\end{array}$ & 1 & Q2 \\
\hline 2020 & Acta Paediatrica & 1 & Q1 \\
\hline 2020 & $\begin{array}{l}\text { Sport, Education and } \\
\text { Society }\end{array}$ & 1 & Q1 \\
\hline 2020 & $\begin{array}{c}\text { Journal of Sport and } \\
\text { Health Science }\end{array}$ & 1 & Q1 \\
\hline 2020 & $\begin{array}{l}\text { Research Expertise } \\
\text { and Collaboration } \\
\text { Edu Sportivo: }\end{array}$ & 1 & Q1 \\
\hline 2020 & $\begin{array}{l}\text { Indonesian Journal } \\
\text { of Physical Education } \\
\text { STAND: Journal }\end{array}$ & 1 & Nasional \\
\hline 2020 & $\begin{array}{l}\text { Sports Teaching and } \\
\text { Development }\end{array}$ & 1 & Nasional \\
\hline 2020 & $\begin{array}{l}\text { Jurnal Pendidikan } \\
\text { Jasmani Indonesia } \\
\text { EduPsyCouns: }\end{array}$ & 1 & Sinta 3 \\
\hline 2020 & $\begin{array}{l}\text { Journal of Education, } \\
\text { Psychology and } \\
\text { Counseling } \\
\text { Jurnal IPTEK-KOM } \\
\text { (Jurnal Ilmu }\end{array}$ & 1 & Sinta 2 \\
\hline 2020 & $\begin{array}{l}\text { Sport Sciences and } \\
\text { Physical Education }\end{array}$ & 1 & Sinta 5 \\
\hline
\end{tabular}

Setelah dipaparkan tabel 1 yang menjelaskan tentang Tahun Terbit Jurnal, Nama Jurnal serta Indeks jurnal. Selanjutnya tabel 2 di bawah akan mengungkapkan mengenai nama penulis, metode penelitian serta temuan hasil penelitian yang berkaitan dengan dampak Covid-19 pada pembelajaran penjas. Untuk mempermudah pencapain hasil penelitian dipaparkan pada tabel 2 .

Tabel 2. Tabel Hasil Analisis Artikel Penelitian

\begin{tabular}{|c|c|c|c|}
\hline No & Penulis & Metode & Temuan Hasil Penelitian \\
\hline 1 & Kan \& Zhou & Survei & $\begin{array}{l}\text { Covid-19 berdampak positif bagi insan } \\
\text { pendidikan terutama para pengajar harus } \\
\text { berinovasi dan membuka pemikiran lebih luas } \\
\text { agar pelajaran tetap berjalan yaitu dengan } \\
\text { salah satu cara Pembuatan buku }\end{array}$ \\
\hline
\end{tabular}


Lanjutan Tabel 2

\begin{tabular}{|c|c|c|c|}
\hline No & Penulis & Metode & Temuan Hasil Penelitian \\
\hline 2 & $\begin{array}{c}\text { Andrew G. Rundle, } \\
\text { Yoosun Park, Julie B, } \\
\text { Herbstman, Eliza W. } \\
\text { Kinsey, and Y. Claire } \\
\text { Wang }\end{array}$ & Kualitatif & $\begin{array}{l}\text { Covid-19 memperburuk dan berdampak pada } \\
\text { meningkatnya obesitas pada anak-anak usia } \\
\text { sekolah dan meningkatkan risiko obesitas } \\
\text { dikarenakan penutupan sekolah dan kegiatan } \\
\text { pembelajaran pendidikan jasmani. }\end{array}$ \\
\hline 3 & $\begin{array}{c}\text { Shahidi, S. H, Stewert W. } \\
\text { J, \& Hassani, F. }\end{array}$ & Survei & $\begin{array}{l}\text { Covid-19 telah berdampak negative yang } \\
\text { membuat membatasi aktivitas fisik pada } \\
\text { orang-orang dari segala usia. Yang membuat } \\
\text { olahraga indoor maupun outdoor dan aktifitas } \\
\text { pembelajaran jasamani di tiadakan dan } \\
\text { ditutup }\end{array}$ \\
\hline 4 & Heidorn, B., & Survey & $\begin{array}{l}\text { covid-19 memberikan dampak pada } \\
\text { pendidikan jasmani saat ini yaitu } \\
\text { menumbuhkan semangat positif dan focus } \\
\text { terhadap pembelajaran virtual sehingga bisa } \\
\text { terus bergerak walaupun hanya dirumah }\end{array}$ \\
\hline 5 & $\begin{array}{c}\text { Valeria Varea \& Gustavo } \\
\text { González-Calvo, }\end{array}$ & Survey & $\begin{array}{l}\text { covid-19 berdampak pada Tingkat emosi } \\
\text { peserta didik di masa lockdown berubah, } \\
\text { bagaimana emosi mereka saat pembelajaran } \\
\text { pendidikan jasmani telah berubah secara } \\
\text { signifikan dari sebelumnya selama masa } \\
\text { pandemi covid-19 }\end{array}$ \\
\hline 6 & $\begin{array}{l}\text { Chen P, Mao L, Nassis } \\
\text { G.P, Hermer P, } \\
\text { Ainsworth B.E, \& Li F }\end{array}$ & Kualitatif & $\begin{array}{l}\text { covid-19 telah berdampak pada pendidikan } \\
\text { jasmani dimana guru harus menerapkan kelas } \\
\text { dengan waktu dan jumlah yang terbatas untuk } \\
\text { membatasi kepadatan }\end{array}$ \\
\hline 7 & $\begin{array}{l}\text { Flho-Silva E, Texeira, } \\
\text { Xavier, Junior, Barbosa, } \\
\text { \& Albuquerque }\end{array}$ & Kualitatif & $\begin{array}{l}\text { covid-19 membuat dampak pada Guru } \\
\text { pendidikan jasmani yang terus diperhatikan } \\
\text { sebagai ahli kesehatan esensial selama } \\
\text { periode pandemi ini karena mereka dapat } \\
\text { membimbing dan merangsang individu untuk } \\
\text { berlatih latihan fisik secara rutin, guna } \\
\text { menjaga dan meningkatkan kesehatannya }\end{array}$ \\
\hline 8 & Setiyawan \& Kresnapati, & Survey & $\begin{array}{l}\text { Covid-19 membuat system pembelajaran } \\
\text { jasamni berubah dari pertemuan tatap muka } \\
\text { menjadi pembelajaran online. }\end{array}$ \\
\hline 9 & $\begin{array}{l}\text { Jauhari, Nurohman, } \\
\text { Sambira, \& Zakia, }\end{array}$ & Survey & $\begin{array}{l}\text { Covid-19 membuat guru pendidikan jasmani } \\
\text { adaptif sulit menjalankan dan memberikan } \\
\text { pembelaaran kepada ABK. }\end{array}$ \\
\hline 10 & $\begin{array}{l}\text { Muhammad Fachrurrozi } \\
\text { Bafadal, Andika } \\
\text { Triansyah, }\end{array}$ & Survey & $\begin{array}{l}\text { covid-19 membuat dampak yang baik bagi } \\
\text { guru karna bisa menggunakan aplikasi Google } \\
\text { form menjadi salah satu aplikasi penilaian } \\
\text { online untuk pembelajaran penjas bagi } \\
\text { mahasiswa maupun dosen karena tampilan } \\
\text { aplikasi mudah dimengerti dan cara } \\
\text { mengoperasikannya cukup sederhana serta } \\
\text { link nya mudah diakses }\end{array}$ \\
\hline
\end{tabular}


Journal of Sport Education (JOPE), 3 (2) 2021 - 98

Muhammad Syofian ${ }^{1 *}$, Novri Gazali ${ }^{2}$

Lanjutan Tabel 2

\begin{tabular}{|c|c|c|c|}
\hline No & Penulis & Metode & Temuan Hasil Penelitian \\
\hline 11 & Agus Purwanto, & Survey & $\begin{array}{l}\text { covid-19 telah membuat semua pendidikan } \\
\text { dilakuan secara Work From Home }\end{array}$ \\
\hline 12 & Sari, & Survey & $\begin{array}{l}\text { covid-19 memberikan dampak positif } \\
\text { terhadap pembelajaran jasmani dimana } \\
\text { pembelajaran PJOK berjalan dengan efektif. } \\
\text { Dengan memanfaatkan google classroom dan } \\
\text { penugasan individu. }\end{array}$ \\
\hline 13 & Setyorini, & Kualitatif & $\begin{array}{l}\text { covid-19 memberikan dampak terhadap insan } \\
\text { pendidikan baik itu guru, murid maupun } \\
\text { orang tua dengan keterbatasan jaringan dan } \\
\text { biaya kebutuhan untuk internet. }\end{array}$ \\
\hline 14 & Palupi, & kuantitatif & $\begin{array}{l}\text { Covid-19 membuat tingkat stress pada siswa } \\
\text { sekolah dasar kelas besar lebih tinggi. }\end{array}$ \\
\hline 15 & $\begin{array}{l}\text { Herlina \& Suherman, } \\
2020\end{array}$ & Kualitatif & $\begin{array}{l}\text { Pembelajaran jasmani di massa covid- } 19 \\
\text { memiliki potensi untuk tetap berjalan dengan } \\
\text { memanfaatkan fasilitas yang ada. }\end{array}$ \\
\hline
\end{tabular}

\section{PEMBAHASAN}

Pada pembahasan akan mengungkapkan hasil analisis yang dilakukan kepada 15 artikel yang sudah dipaparkan pada hasil yang menjadi sumber penelitian. Pembahasan ini akan memaparkan bagaimana dampak Covid-19 terhadap pembelajaran e-learning penjas. Dampak yang didapatkan terbagi menjadi positif dan negatif. Dampak positif bagi insan pendidikan terutama para pengajar harus berinovasi dan membuka pemikiran lebih luas agar pelajaran tetap berjalan yaitu dengan salah satu cara pembuatan buku (Kan \& Zhou, 2020), dan dapat menumbuhkan semangat positif dan fokus terhadap pembelajaran virtual sehingga bisa terus bergerak walaupun hanya di rumah (Heidorn, 2020). Hal ini dilakukan untuk mendorong siswa terus bergerak di rumah dan terus belajar dengan buku panduan yang ada. Pembelajaran pendidikan jasmani dilakukan dengan cara siswa melihat panduan yang ada kemudian melakukan gerakan sesuai buku panduan. Covid-19 juga membuat dampak yang baik bagi guru karna bisa menggunakan aplikasi Google Form menjadi salah satu aplikasi penilaian online untuk pembelajaran pendidikan jasmani bagi mahasiswa maupun dosen karena tampilan aplikasi mudah dimengerti dan cara mengoperasikannya cukup sederhana serta linknya mudah diakses (Bafadal, 2020).

Sedangkan sangat banyak dampak negatif pada masa pandemi Covid-19 terhadap pendidikan jasmani. Dalam temuan Rundle et al., (2020) menyebutkan bahwa pandemi virus Covid-19 memperburuk dan berdampak pada meningkatnya obesitas pada anak-anak usia sekolah dan meningkatkan risiko obesitas dikarenakan penutupan sekolah dan kegiatan pembelajaran pendidikan jasmani. Padahal pendidikan jasmani membantu anak dalam menurunkan berat badan dan menjaga kesehatannya, sehingga ketika semua berubah seperti saat ini, mereka lebih banyak berdiam diri. Sehingga guru harus bisa membuat bagaimana pembelajaran pendidikan jasmani terus bisa berjalan untuk mengurangi resiko obesitas pada anak. Pandemi Covid-19 telah berdampak negatif yang membuat membatasi aktivitas fisik pada orang-orang dari segala usia, yang membuat olahraga indoor maupun outdoor dan aktifitas pembelajaran jasmani ditiadakan dan ditutup (Shahidi et al., 2020).

Varea et al., (2020) menyatakan bahwa covid-19 berdampak pada tingkat emosi peserta didik di masa lockdown berubah, bagaimana emosi mereka saat pembelajaran pendidikan jasmani telah berubah secara signifikan dari sebelumnya selama masa pandemi covid-19. 
Pandemi membuat para siswa memiliki tingkat emosi yang tidak stabil dalam melakukan pembelajaran pendidikan jasmani. Hal ini karena pendidikan jasmani tidak dilakukan seperti biasanya dan menuntut mereka untuk menghadapi hal baru yang belum mereka hadapi sebelumnya seperti pembelajaran pendidikan jasmani yang dilaksanakan secara online.

Covid-19 telah berdampak pada guru pendidikan jasmani dimana guru harus menerapkan kelas dengan waktu dan jumlah yang terbatas untuk membatasi kepadatan (Chen et al., 2020). Covid-19 juga membuat sistem pembelajaran pendidikan jasmani berubah dari pertemuan tatap muka menjadi pembelajaran online (Setiyawan \& Kresnapati, 2020). Saat ini pembelajaran pendidikan jasmani hanya bisa dilakukan dengan sistem online. Sehingga membuat perubahan yang drastis dalam sistem pembelajaran pendidikan jasmani yang ada. Pada dasarnya pembelajaran dengan sistem online atau e-learning sangat berguna untuk memudahkan siswa dan guru dalam berinteraksi (Rahmatullah, 2019).

Pada guru pendidikan jasmani yang terus diperhatikan sebagai ahli kesehatan esensial selama periode pandemi ini karena mereka dapat membimbing dan merangsang individu untuk berlatih latihan fisik secara rutin, guna menjaga dan meningkatkan kesehatannya (Filho et al., 2020). Dampak ini membuat guru jasmani sangat penting bagi siswa. Karena guru jasmani membuat siswa terus menjaga fisiknya agar imun tubuh setiap siswa tetap terjaga dengan baik. Dampak ini membuat guru jasmani sangat penting bagi siswa. Karena guru jasmani membuat siswa terus menjaga fisiknya agar imun tubuh setiap siswa tetap terjaga dengan baik.

Pada guru pendidikan jasmani adaptif, covid-19 telah membuat guru pendidikan jasmani adaptif sulit menjalankan dan memberikan pembelajaran kepada ABK (Jauhari et al., 2020). Pendidikan jasmani di sekolah luar biasa juga mengalami gangguan pembelajaran, yang membuat mereka tidak bisa menyalurkan energi yang mereka miliki melalui kegiatan olahraga, dan juga menyulitkan guru agar lebih dekat dengan mereka. Covid-19 juga memberikan dampak terhadap insan pendidikan dimana ada problem yang dialami oleh guru, orang tua dan peserta didik dalam pembelajaran online seperti kurangnya pengetahuan teknologi, dan masalah biaya pembelian kuota internet (Setyorini, 2020). Covid-19 membuat setiap insan pendidikan harus berusaha untuk terus menjalankan pendidikan dengan usahausaha yang diakukan. Selain itu, tingkat stress siswa sekolah dasar kelas besar lebih tingi (Palupi, 2020). Baik pembelajaran pendidikan jasmani maupun pembelajaran yang lain membuat beberapa tingkatan siswa mengalami stress yang berebeda. Hal ini dikarnakan pendidikan jasmani dan lainnya dilakukan secara online dan tidak seperti biasanya.

Covid-19 memberikan dampak terhadap pembelajaran pendidikan jasmani dimana pembelajaran PJOK dengan daring berjalan efektif. Google classroom menjadi aplikasi yang efektif dengan menggunakan penugasaan individu (Sari, 2020). Pembelajaran saat ini membuat setiap guru harus menggunakan beberapa aplikasi yang bisa dimanfaatkan untuk menunjang pembelajaran. Dimana google classroom merupakan aplikasi yang efektif digunakan sehingga membawa dampak yang positif bagi pembelajaran. Pembelajaran pendidikan jasmani memiliki potensi untuk terus berjalan di masa pandemi seperti ini dengan segala keterbatasan yang ada (Herlina \& Suherman, 2020). Dampak dari covid-19 memang sangat terasa namun semua memiliki jalannya. Setiap pembelajaran baik pembelajaran jasmani maupun pembelajaran yang lain memiliki potensi untuk terus berjalan. Sehingga membuat tujuan pembelajaran tetap bisa dilakukan walaupun pasti ada kendalanya.

Dari beberapa penelitian di atas yang dibahas memiliki kesamaan yang menimbulkan dampak negatif seperti hambatan saat pembelajaran daring, koordinassi komunikasi antara siswa dan guru menjadi kurang maksimal. Kemudian ketersedian jaringan internet yang tidak merata di daerah membuat pembelajaran menjadi terhambat. Namun dari banyak 
dampak negatif yang dialami juga ada dampak positif yang dialami di antaranya guru menjadi lebih invatif dan kreatif. Membuat siswa dan guru mengerti tentang teknologi dan pembelajaran secara online. Membuat orang tua bisa lebih dekat dengan orang tuanya khususnya dalam mengawasi proses belajar anak.

\section{SIMPULAN}

Berdasarkan hasil analisis dari sumber kajian literatur dapat ditarik kesimpulan yaitu, pembelajaran pendidikan jasmani memiliki dampak positif serta negatif dalam pelaksanaanya saat terjadi pandemi Covid-19. Dampak positif yang dihadirkan adalah pembelajaran memiliki inovasi yang baik serta penggunaan teknologi dalam media pembelajaran mampu memberikan pengetahuan baru kepada pengajar serta siswa dan media tersebut dapat dijadikan sarana dalam menunjang keberhasilan. Meskipun memiliki dampak positif, dampak negatif yang ada adalah kurangnya pergerakan aktivitas fisik yang dilakukan oleh siswa dikarenakan tidak adanya pembelajaran tatap muka mengakibatkan naiknya berat badan serta kurangnya kebugaran siswa. Dampak negatif lainya adalah siswa dan guru diharuskan mengeluarkan anggaran lebih untuk membeli kuota dikarenakan pembelajaran berlangsung daring.

\section{DAFTAR PUSTAKA}

Bafadal, M. F., \& Triansyah, A.. (2020). Formulir Google: Penilaian Alternatif Pendidikan Fisik Sebagai Covid-19. SCIENCE TECH: Jurnal Ilmu Pengetahuan dan Teknologi, 6286(2), 4857.

Chen, P., Mao, L., Nassis, G. P., Harmer, P., Ainsworth, B. E., \& Li, F. (2020). Returning Chinese school-aged children and adolescents to physical activity in the wake of COVID-19: Actions and precautions. Journal of Sport and Health Science, 00, 4-6. https://doi.org/10.1016/j.jshs.2020.04.003

Guan, W., Ni, Z., Hu, Y., Liang, W., Ou, C., He, J., Liu, L., Shan, H., Lei, C., Hui, D. (2020). Clinical characteristics of coronavirus disease 2019 in China. New England Journal of Medicine, 382(18), 1708-1720. https://doi.org/10.1056/NEJMoa2002032

Heidorn, B. (2020). Provide and Protect the Essential Components. Journal of Physical Education, Recreation and Dance, 3-5. https://doi.org/10.1080/07303084.2020.1748482

Herliandry, L. D., Nurhasanah, N., Suban, M. E., \& Kuswanto, H. (2020). Pembelajaran Pada Masa Pandemi Covid-19. JTP - Jurnal Teknologi Pendidikan, 22(1), 65-70.

Herlina, H., \& Suherman, M. (2020). Potensi Pembelajaran Pendidikan Jasmani Olahraga Dan Kesehatan (Pjok) Di Tengah Pandemi Corona Virus Disease (Covid)-19 Di Sekolah Dasar. Tadulako Journal Sport Sciences And Physical Education, 8(1), 1-7. http://jurnal.untad.ac.id/jurnal/index.php/PJKR/article/view/16186

Hudah, M., Widiyatmoko, F. A., Pradipta, G. D., \& Maliki, O. (2020). Analisis Pembelajaran Pendidikan Jasmani Di Masa Pandemi Covid-19 Di Tinjau Dari Penggunaan Media Aplikasi Pembelajaran Dan Usia Guru. Jurnal Porkes, 3(2), 93-102. https://doi.org/10.29408/porkes.v3i2.2904

Jauhari, M. N., Mambela, S., \& Zakiah, Z. (2020). Dampak Pandemi Covid-19 Terhapad 
Pelaksanaan Pembelajaran Penjas Adaptif Di Sekolah Luar Biasa. STAND, 1(1), 63-70.

Kan, M., \& Zhou, J. (2020). How Do Colleges and Universities Respond to Covid-19: The Experience of Chengdu Sport University. Asia-Pacific Journal of Public Health, 2, 2-3. https://doi.org/10.1177/1010539520931358

Kurniasih, E. (2020). Pembelajaran Pendidikan Jasmani Saat Pandemic Makalah. Researchgate, June. $\quad$ https://doi.org/https://www.researchgate.net/publication/342491671 Pembelajaran

Kurniawan, M. T. A. (2020). Artikel Review: Dampak Pandemi Covid-19 Terhadap Pendidikan Di Indonesia. Seminar \& Conference Nasional ..., 111-117.

Lee, A. (2020). Wuhan novel coronavirus (COVID-19): why global control is challenging? On. Public Health 179, 1-2(January), 19-21. https://doi.org/https://doi.org/10.1016/j.puhe.2020.02.001

Mahase, E. (2020). Coronavirus covid-19 has killed more people than SARS and MERS combined, despite lower case fatality rate. BMJ (Clinical Research Ed.), 368(February), m641. https://doi.org/10.1136/bmj.m641

Palupi, T. N. (2020). Tingkat Stres Pada Siswa-Siswi Sekolah Dasar Dalam Menjalankan Proses Belajar Di Rumah Selama Pandemi Covid-19. Journal Psikologi dan Pengembangan SDM, 9(2), 18-29.

Purwanto, A. (2020). Studi Eksplorasi Dampak Work From Home (WFH) Terhadap Kinerja Guru Selama Pandemi Covid-19. EduPsyCounsJournal, Journal of Education, Psychology and Counseling, 2, 92-100.

Rahmatullah, M. I. (2019). Pengembangan Konsep Pembelajaran Literasi Digital Berbasis Media E-Learning Pada Mata Pelajaran PJOK di SMA Kota Yogyakarta. Journal Of Sport Education (JOPE), 1(2), 56-65.

Rundle, A. G., Park, Y., Herbstman, J. B., Kinsey, E. W., \& Wang, Y. C. (2020). COVID-19-Related School Closings and Risk of Weight Gain Among Children. Obesity, 28(6), 1008-1009. https://doi.org/10.1002/oby.22813

Sari, D. P., \& P. S. (2020). Efektivitas Pembelajaran Jarak Jauh Dengan Daring Selama Pandemi Covid-19 Mata Pelajaran Pendidikan Jasmani Olahraga dan Kesehatan (PJOK). Pediatric Critical Care Medicine, 19-29.

Setiyawan, K., Setiawan, P., \& Aji, D. (2020). Analisis perkuliahan daring mahasiswa PJKR Universitas PGRI Semarang sebagai dampak pandemi covid 19. Edu Sportivo, 1(1), 25-32.

Setyorini, I. (2020). Pandemi Covid-19 Dan Online Learning : Apakah Berpengaruh Terhadap Proses Pembelajaran Pada Kurukulum 13. Journal of Industrial Engineering \& Management Research ( JIEMAR ), 95-102.

Shahidi, S. H., Stewart Williams, J., \& Hassani, F. (2020). Physical activity during COVID-19 quarantine. Acta Paediatrica, 0-1. https://doi.org/10.1111/apa.15420 
Silva-Filho, E., Teixeira, A. L. S., Xavier, J. R. da S., Braz Júnior, D. da S., Barbosa, R. A., \& Albuquerque, J. A. de. (2020). Physical education role during coronavirus disease 2019 (COVID-19) pandemic Physical education and COVID-19. Motriz: Revista de Educação Física, 26(2), 2019-2020. https://doi.org/10.1590/s1980-6574202000020086

Sohrabi, C., Alsafi, Z., Neill, N. O., Khan, M., \& Kerwan, A. (2020). World Health Organization declares global emergency: A review of the 2019 novel coronavirus (COVID-19) Catrin. International Journal of Surgery Journal, 76(January), 71-76.

Sulaksono, G., \& Wibowo, A. (2021). Studi Deskriptif Pelaksanaan Pendidikan Jasmani Olahraga dan Kesehatan pada Tingkat SMA Kelas XI Selama Masa Pandemi Covid-19. Olaharaga, 7(1), 82-90.

Varea, V., González-calvo, G., \& Varea, V. (2020). Touchless classes and absent bodies: teaching physical education in times of Covid-19 in times of Covid-19. Sport, Education and Society, O(0), 1-15. https://doi.org/10.1080/13573322.2020.1791814 